\title{
Consistency of Agricultural, Forestry and Mining Policies with Sustainable Forest Management in the East and South Regions of Cameroon
}

\author{
Jervais Nkoulou¹, Dieudonné Bitondo², Richard Eba'a Atyi³, Claude Bakoume ${ }^{4}$ \\ ${ }^{1}$ Pan African Institute for Development (PAID), Yaoundé, Cameroon \\ ${ }^{2}$ University of Dschang, Dschang, Cameroon \\ ${ }^{3}$ Center for International Forestry Research (CIFOR), Central Africa Hub, Yaoundé, Cameroon \\ ${ }^{4}$ Maxi Productivity Sarl, Douala, Cameroun \\ Email: nkouloujervais@yahoo.fr, bitondodieudonne@yahoo.fr, r.atyi@cgiar.org, claude.bakoume@maxiproductivity.com
}

How to cite this paper: Nkoulou, J., Bitondo, D., Atyi, R.E. and Bakoume, C. (2021) Consistency of Agricultural, Forestry and Mining Policies with Sustainable Forest Management in the East and South Regions of Cameroon. Natural Resources, 12, 205-222. https://doi.org/10.4236/nr.2021.127015

Received: April 9, 2021

Accepted: July 20, 2021

Published: July 23, 2021

Copyright $\odot 2021$ by author(s) and Scientific Research Publishing Inc. This work is licensed under the Creative Commons Attribution International License (CC BY 4.0).

http://creativecommons.org/licenses/by/4.0/

\section{(c) (i) Open Access}

\begin{abstract}
The eastern and southern regions of Cameroon, lower middle income country, need to increase their level of land use by the agricultural, forestry and mining sectors in order to develop. At the same time, Cameroon is committed to managing its forests sustainably to meet the needs of present and future generations. This study assesses the compatibility of agricultural, forestry and mining policies with sustainable forest management in the East and South forest regions. Five analytical criteria were used and the analysis was carried out through surveys of key informants in the private sector, public administrations and civil society. The study showed that from 2013 to 2018, the contributions of the agricultural, forestry and mining sectors to GDP grew by about $74 \%, 65 \%$ and $60 \%$, respectively. Agricultural, forestry and mining policies have an average compatibility rate of $45 \%$ with sustainable forest management, of which $52 \%$ for the forestry sector, $43 \%$ for the agricultural sector and $40 \%$ for the mining sector. Nonetheless, there are 21 causes of incompatibility, including 1) the non-involvement of all relevant public administrations in policy-making, 2) the low efficiency of the control system of exploitation activities, and 3) the poor coordination of actions in the three sectors. It was proposed to a) improve the legal and regulatory framework of the three sectors of activity and b) develop land-use planning tools among other measures to align existing policies with sustainable forest management.
\end{abstract}

\section{Keywords}

Agricultural Sector, Forestry Sector, Mining Sector, Sectoral Policy, 
Economic Development, Deforestation, Cameroon

\section{Introduction}

The Cameroon forest cover is 22.5 million hectares. It is the third largest forest in the Congo Basin after those of the Democratic Republic of Congo and Gabon [1]. The forests of the East and South Regions account for 75\% of the country's production forests and $63 \%$ of its protected areas. They provide huge nutritional supplements, medicines, fuelwood and building materials to the people of these two regions [2]. They are also a reserve for agricultural land and extractive activities such as mining and logging.

The contribution of Cameroon's forestry sector to GDP increased from 2.76\% between 2008 and 2010 to $3.51 \%$ in 2017 [3] [4]. It was higher than that of the mining sector, estimated at $0.18 \%$, and much lower than that of the agricultural sector, which was $17.5 \%$ in 2010 [3]. The contribution of Cameroon's forests, in general, and of the East and South Regions, in particular, to socio-economic development is set to increase in order to enable the country to attain the status of an emerging country [5]. Achieving this objective requires an increase in production levels and the modernisation of the production apparatus of the forestry, agricultural and mining sectors. Modernisation of the forestry sector requires further processing of wood [6]. For the agricultural sector, yields and surface areas need to be increased by around 30\% compared to 2005 levels in order to ensure food security and strengthen growth and employment in this sector. In the mining sector, there is a need to intensify the exploration, exploitation and processing of the various known deposits [5]. The expansion of these activities in all three sectors will inevitably lead to increased deforestation.

Alongside the socio-economic development of the two regions, it is necessary to ensure that forests are conserved because of their role in the fight against climate change. That is why Cameroon has signed all the international conventions related to environmental protection, notably the Convention on Biological Diversity and the UN Framework Convention on Climate Change. The country is also committed to promoting instruments and actions that allow for streamlined management of its forest resources.

All three sectors share land as a resource and are the main drivers of deforestation in the Congo Basin [7] [8]. In fact, logging and mining activities on the ground significantly compromise forest regeneration in the East (Figure 1) and South (Figure 2) Regions of the country.

The sectoral approach to the management of development sectors allows for better planning and ownership of actions to be taken for the deployment of a given sector of activity. However, to be effective and not generate conflicts between actors, the sectoral approach must hinge on consistency of interventions between sectors of activity that use the same resources. Such an approach reduces the dispersion of administrative capacities and leads to greater efficiency in 


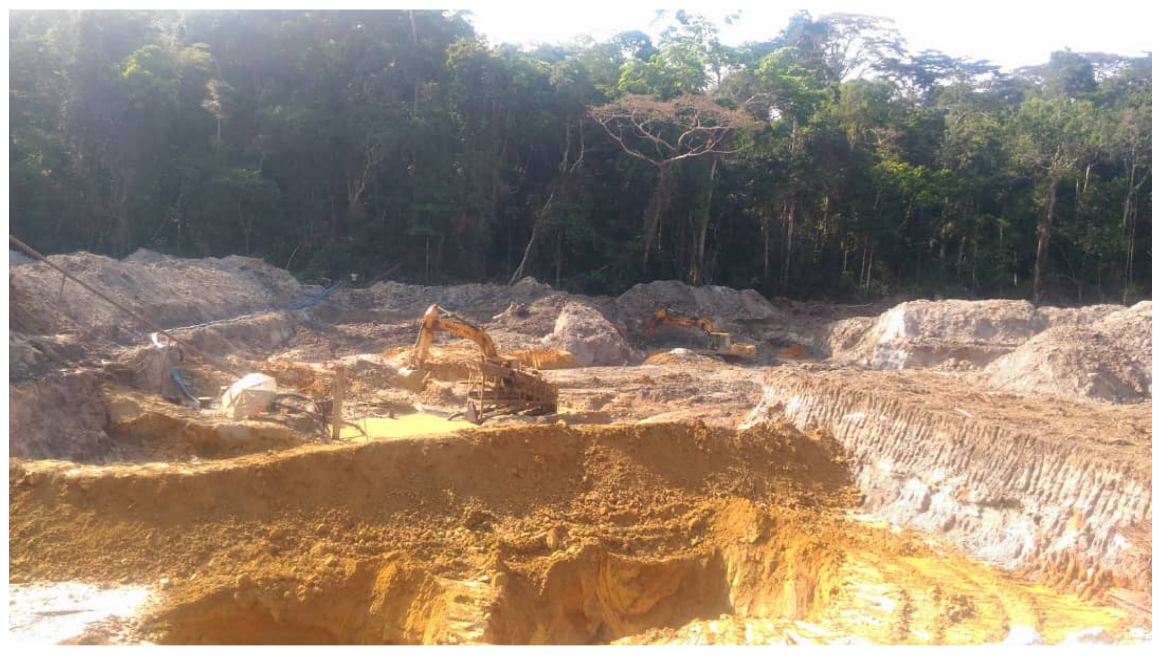

Figure 1. Forest loss and soil destruction in a mining operation in the east region of Cameroon.

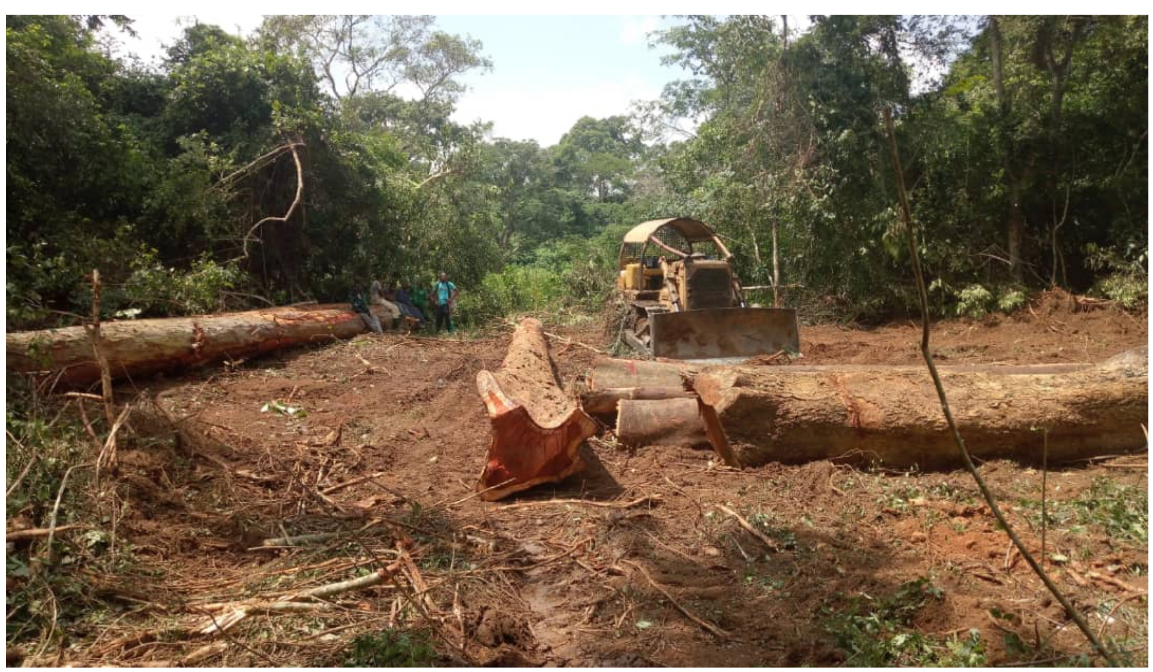

Figure 2. Forest and soil degradation in a logging operation in the south region of Cameroon.

achieving common objectives [9]. Also, it is important to promote the harmonisation of sectoral policies in order to produce a common leverage effect and to make the rules of the game clear and predictable to stakeholders [10]. In fact, consistency in sectoral policies is about promoting mutual reinforcement and synergy of sectoral policies so that they can achieve their intended objectives [11]. The objectives of this work are economic development and sustainable forest management.

This study seeks to 1) determine whether the policies adopted by Cameroon to increase the contribution of the agricultural, forestry and mining sectors to the country's economic development are compatible with SFM, 2) determine the degree of compatibility as well as the causes of incompatibility, and 3) suggest measures to harmonise these three sectoral policies with SFM in the East and South Regions of Cameroon. 


\section{Materials and Methods}

\subsection{Materials}

For each of the sectors, policy, strategy and legal and institutional framework documents were collected. In all, eight documents were consulted, four of which were on the forestry sector, three on the agricultural sector and one on the mining sector (Table 1). A sector policy document sets out the vision, guiding principles, objectives and expected impact of the development of the sector concerned. The sector strategy states and outlines the actions to be taken and the resources to be used for the implementation of a given policy. The legal and institutional framework document stipulates a set of rules and prescriptions that should guide in a concrete manner the activities of the various actors involved in the implementation of the policy.

Surveys were also carried out with key informants in the government ministries concerned.

Surveys were conducted with government officials in the three relevant sectors of activity under the Ministry of Forestry and Wildlife (MINFOF), the Ministry of Agriculture and Rural Development (MINADER) and the Ministry of Mines, Industry and Technological Development (MINMIDT). Stakeholders from the private sector and civil society were also met (Table 2 ).

\subsection{Methods}

\subsubsection{Data Collection}

The surveys were conducted in the form of semi-structured interviews, which are more suitable for qualitative studies than questionnaires. Questionnaires appear to be more suitable for collecting more general data from large samples [17]. The interviews focused on five themes, namely 1 ) the influence of various actors on policy-making, 2) the contribution of each sector to local development and the national economy, 3) the practices adopted for arbitrating conflicts between actors in various sectors, 4) the effectiveness of arrangements for intersectoral coordination, and 5) the existence and functioning of monitoring and evaluation mechanisms.

Table 1. Documents used per sector studied.

\begin{tabular}{|c|c|}
\hline Sector & Document consulted \\
\hline Forestry sector & 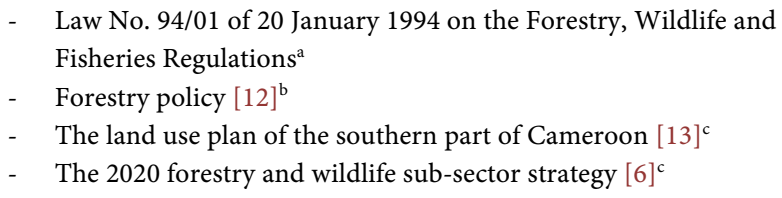 \\
\hline Agricultural sector & $\begin{array}{l}\text { - } \quad \text { The agricultural policy document }[14]^{\mathrm{b}} \\
\text { - } \quad \text { The Agriculture and Rural Development Sector Development } \\
\text { Strategy (SDADR), }[15]^{\mathrm{c}} \\
\text { - } \quad \text { The National Agricultural Investment Plan (PNIA), }[16]^{\mathrm{c}}\end{array}$ \\
\hline Mining sector & - $\quad$ Law No. $2016 / 17$ of 14 December 2016 on the mining code ${ }^{a}$ \\
\hline
\end{tabular}

${ }^{\mathrm{a}}$ Legal and institutional framework, ${ }^{\mathrm{b}}$ Policy document, ${ }^{\mathrm{c} S t r a t e g y}$ document. 
Table 2. Details of interviewees.

\begin{tabular}{|c|c|c|c|}
\hline Ministry & Sector & Service/Organisation & $\begin{array}{l}\text { Number } \\
\text { of people }\end{array}$ \\
\hline \multirow{6}{*}{ MINFOF } & \multirow{6}{*}{ Forestry } & East Regional Delegation & 2 \\
\hline & & South Regional Delegation & 2 \\
\hline & & Ocean Divisional Delegation & 2 \\
\hline & & Boumba and Ngoko & 2 \\
\hline & & Divisional Delegation & \\
\hline & & Kadey Divisional Delegations & 1 \\
\hline \multirow{4}{*}{ MINADER } & \multirow{4}{*}{ Agricultural } & East Regional Delegation & 2 \\
\hline & & South Regional Delegation & 2 \\
\hline & & Dja and Lobo Divisional Delegation & 1 \\
\hline & & Ocean Divisional Delegation & 1 \\
\hline \multirow{3}{*}{ MINMIDT } & \multirow{3}{*}{ Mining } & East Regional Delegation & 2 \\
\hline & & South Regional Delegation & 1 \\
\hline & & Kadey Divisional Delegation & 1 \\
\hline \multirow{5}{*}{ Civil society } & \multirow{5}{*}{$\begin{array}{l}\text { Forestry } \\
\text { Agricultural } \\
\text { Mining }\end{array}$} & $\begin{array}{l}\text { Cercle de promotion des forêts et des } \\
\text { initiatives locales de développement (CEPFILD) }\end{array}$ & 1 \\
\hline & & $\begin{array}{l}\text { Centre pour l'éducation, la formation et l'appui } \\
\text { aux initiatives de } \\
\text { développement (CEFAID) }\end{array}$ & 1 \\
\hline & & $\begin{array}{l}\text { Protection de l'environnement et recherche } \\
\text { pour l'appui au développement (PERAD) } \\
\text { Organisation d'appui à l'auto promotion et à }\end{array}$ & 1 \\
\hline & & $\begin{array}{l}\text { l'insertion des femmes, des jeunes et des } \\
\text { désœuvrés (APIFED) }\end{array}$ & 1 \\
\hline & & $\begin{array}{l}\text { Centre de recherché et d'appui au } \\
\text { développement (CERAD) }\end{array}$ & 1 \\
\hline \multirow{8}{*}{ Private sector } & \multirow{8}{*}{$\begin{array}{l}\text { Forestry } \\
\text { Agricultural } \\
\text { Mining }\end{array}$} & Vicwood Thanry & 2 \\
\hline & & $\begin{array}{l}\text { Société camerounaise d'industrie } \\
\text { et d'exploitation de bois (SCIEB) }\end{array}$ & 1 \\
\hline & & AlpiCameroon (Alpicam) & 1 \\
\hline & & $\begin{array}{l}\text { Bureau d'études de diagnostic } \\
\text { et de prospective (BUREDIP) }\end{array}$ & 1 \\
\hline & & Sud Hévéa & 2 \\
\hline & & Hevecam & 2 \\
\hline & & Caminex & 1 \\
\hline & & C\&K Mining Inc & 1 \\
\hline Total & & & 35 \\
\hline
\end{tabular}

\subsubsection{Data Analysis}

Five parametric criteria for sustainable forest management were selected to analyse the compatibility between each sectoral policy and sustainable forest management (Table 3). They were inspired by the work of [18] [19] [20] [21].

The performance level of these criteria was assessed using three qualification scales associated with a rating (Table 4) inspired by the work of the FAO [22].

The compatibility analysis was carried out at four levels, namely 1) at the level of each indicator, 2) at the level of each criterion, 3) at the level of each sector of activity and 4) at the level of the three sectors put together. The criterion score is the arithmetic average of the indicator scores. The sector score is the arithmetic 
Table 3. Analysis criteria and indicators used.

\begin{tabular}{|c|c|}
\hline Criterion & Indicators \\
\hline $\begin{array}{l}\text { Stakeholder participation in } \\
\text { policy-making }\end{array}$ & $\begin{array}{l}\text { - } \quad \text { Number of participating stakeholders } \\
\text { - } \quad \text { Involvement in the definition of strategic choices }\end{array}$ \\
\hline $\begin{array}{l}\text { Rules governing access to the } \\
\text { resource }\end{array}$ & $\begin{array}{l}\text { - Existence of an inventory of the resource to be } \\
\text { managed } \\
\text { - Involvement of other sectors in the leasing process } \\
\text { - Controlling the development of the sector's land } \\
\text { tenure }\end{array}$ \\
\hline $\begin{array}{l}\text { Three pillars of sustainable } \\
\text { management (economic, social } \\
\text { and environmental) }\end{array}$ & $\begin{array}{l}\text { - } \begin{array}{l}\text { Involvement of local people in resource management } \\
\text { - }\end{array} \text { Existence of tax and royalty sharing mechanisms } \\
\text { - } \quad \text { Environmental protection } \\
\text { - } \quad \text { Contribution of the sector to economic growth } \\
\text { through GDP and formal employment }\end{array}$ \\
\hline $\begin{array}{l}\text { Inter-sectoral coordination and } \\
\text { provision of arbitration mechanisms }\end{array}$ & $\begin{array}{l}\text { - } \quad \text { Existence of a formal technical coordination body } \\
\text { - Capacity of the coordination body to anticipate } \\
\text { possible conflicts between actors } \\
\text { - } \quad \text { Fairness of arbitration procedures }\end{array}$ \\
\hline $\begin{array}{l}\text { Provision of a monitoring and } \\
\text { evaluation mechanism }\end{array}$ & $\begin{array}{l}\text { Existence of a structure in charge of monitoring and } \\
\text { evaluation in each ministry } \\
\text { - Existence of a database and relevance of the data } \\
\text { collected to inform the revision of the sector policy }\end{array}$ \\
\hline
\end{tabular}

Table 4. Assessment of sectoral policy review criteria.

\begin{tabular}{ccc}
\hline Level of performance & $\begin{array}{c}\text { Level of satisfaction } \\
\text { of the indicator }\end{array}$ & Rating (\%) \\
\hline Low & Not satisfied & 25 \\
Medium & Partially satisfied & 50 \\
High & Fully satisfied & 100 \\
\hline
\end{tabular}

average of the criteria scores and the score for the three sectors is the weighted average of the score for each sector. In fact, given that the three sectors do not have the same level of impact on deforestation in Cameroon, we used weighting coefficients to take into account the weight of each sector on forest cover loss. Deforestation data published [23] allowed us to assign the following coefficients per sector: mining (1), forestry (3) and agriculture (6).

Consistency entails, on the one hand, of analysing the causes or sources of incompatibility between the three sectoral policies and the sustainable forest management (SFM) criteria and, on the other hand, of determining the most important causes.

Finally, on the basis of the types of cases thus identified, proposals for harmonisation were made. These were measures to be put in place to make the three policies compatible with SFM.

\section{Results}

The analysis of the compatibility of the various sectoral policies with the SFM 
criteria has shown points of convergence and divergence that vary according to the sector (Table 5).

Indicators with a low or medium degree of compatibility with SFM criteria are in italics.

The compatibility rates of the various policies with the criterion of stakeholder participation in policy-making were estimated as follows: $50 \%$ for the forestry sector, $60 \%$ for the agricultural sector, and $75 \%$ for the mining sector.

The assessment of the compatibility of the three sectoral policies with the criterion of stakeholder participation in policy-making showed that the agricultural sector has a level of stakeholder involvement comparable to that of the three sectors put together (Figure 3).

The three sectors have an average compatibility of $62 \%$ with the criterion of stakeholder participation in policy-making.

The parametric assessment of access to the resource showed that the forestry sector had the highest compatibility (80\%) and the agricultural sector the lowest $(25 \%)$. The three sectors together have an average compatibility of $46 \%$ with the criterion of defining rules governing access to the resource (Figure 4).

The forestry policy has a $70 \%$ compatibility rate with the social and economic components considered in this study. Data collected at MINFOF show that the surface area allocated to community forests increased from 498,017 ha in 2009 to $1,510,238$ ha in $2018(+203 \%)$ in the East and South Regions. During the same period, the surface area of council forests increased from 471,846 ha to $1,180,961$ ha $(+150 \%)$ in both regions.

With regard to the sectors' contribution to major economic aggregates, the data collected indicate that the forestry sector's contribution to GDP rose from CFA 361.2 billion to CFA 559.3 billion from 2013 to 2018, an increase of almost 65\%. In 2017 , the forestry sector had 161 formal companies with a turnover of CFAF 210,404 billion and 7686 employees.

However, the contribution of logging to deforestation remains significant. In addition, the implementation of environmental management plans resulting from Environmental Impact Assessments (EIA) has not been done in an optimal manner.

The agricultural sector makes a considerable contribution to improving living conditions in rural areas. The contribution of the agricultural sector to GDP rose from CFA 1571.5 billion to CFA 2136.7 billion from 2013 to 2018, i.e. a growth of about $74 \%$. In terms of employment, the agricultural sector had 105 formal companies for 27,927 jobs in 2017, while the turnover of companies in the agricultural sector was CFA 251,371 billion in the same year. In fact, the agricultural policy is $70 \%$ compatible with the presence criterion of the sustainability pillars.

The mining code has formalised mining by small-scale miners, including people living near mining deposits. This formalisation was achieved through the institution of artisanal mining permits, the exploitation of which was reserved exclusively for natural persons of Cameroonian nationality. The key informants 
Table 5. Compatibility of sectoral policies with SFM criteria.

\begin{tabular}{|c|c|}
\hline Criteria & Analysis \\
\hline $\begin{array}{c}\text { Stakeholder } \\
\text { participation in } \\
\text { policy-making }\end{array}$ & $\begin{array}{l}\text { Forestry sector } \\
\text { - Involvement of all relevant stakeholders in the development of the land use } \\
\text { - } \quad \text { Stron and the } 2020 \text { strategy. } \\
\text { options of the } 2020 \text { strategy. } \\
\text { - Non-participation of councils, communities and ministries in charge of mines, } \\
\text { agriculture and land use planning in the formulation of the policy document } \\
\text { and the forestry law. } \\
\text { - Definition of strategic options of the forestry law and policy by the State and } \\
\text { the World Bank. } \\
\text { - Low involvement of the agricultural and mining administrations in the } \\
\text { definition of the strategic choices of the land use plan, given that forestry } \\
\text { aspects have been given priority. } \\
\text { Agricultural sector } \\
\text { - Involvement of all relevant stakeholders in the development of the PNIA and } \\
\text { the SDADR. } \\
\text { - Involvement of all relevant stakeholders in the formulation of the strategic } \\
\text { options of the PNIA and the SDADR. } \\
\text { Involvement of all relevant actors in the development of the agricultural policy } \\
\text { document with the exception of the mining administration and RLAs. } \\
\text { - Formulation of strategic options of the agricultural policy by the State and } \\
\text { development partners. } \\
\text { Mining sector } \\
\text { - Participation of all relevant stakeholders in the development of the mining } \\
\text { code. } \\
\text { Formulation of strategic options for the mining code by the State and } \\
\text { development partners. The involvement of other stakeholders (MINFOF, } \\
\text { MINADER, CTD, civil society, private sector) was limited to consultations. }\end{array}$ \\
\hline
\end{tabular}

Forestry sector

- All industrial logging titles are awarded by tender.

- Allocations are made by an inter-ministerial commission in which non-governmental actors (MPs, trade unions, independent observer) also participate.

- MINFOF has two databases for monitoring the forest land tenure: the forest information management system and the forest cover evolution monitoring system.

- Forest inventory carried out on part of the national territory, i.e. 14,011,127 hectares representing $64 \%$ of the country's evergreen forests and the entire

Rules governing access to the resource 


\section{Continued}

\begin{tabular}{|c|c|}
\hline $\begin{array}{l}\text { SFM pillars } \\
\text { (economic, } \\
\text { social and } \\
\text { environmental) }\end{array}$ & $\begin{array}{l}\text { Forestry sector } \\
\text { - Communities and councils are involved in logging through community and } \\
\text { council forests. } \\
\text { - The contribution of the forestry sector to the main economic aggregates } \\
\text { (GDP and job creation) is lower than agriculture and higher than mining } \\
\text { - The contribution of logging to deforestation is significant and the } \\
\text { implementation of environmental management plans weak. } \\
\text { - } \quad \text { Agricultural sector } \\
\text { - Communities are heavily involved in the agricultural sector through family } \\
\text { farms which contribute to food security and are the primary source of income } \\
\text { for many households } \\
\text { - The contribution of the agricultural sector to major economic aggregates } \\
\text { (GDP and jobs) is the highest of the three sectors } \\
\text { - The agricultural sector is the main driver of deforestation in Cameroon } \\
\text { Mining sector } \\
\text { - Communities are involved in mining through artisanal mining. Contrary to } \\
\text { the law, almost all the artisanal titles allocated are exploited by the Chinese. } \\
\text { The small part of the ad valorem tax intended for the communities reaches } \\
\text { them in a derisory way. } \\
\text { The contribution of the mining sector to the main economic aggregates (GDP } \\
\text { and job creation) is the lowest of the three sectors. } \\
\text { Mining causes uncontrolled damage to the environment and severely } \\
\text { compromises forest regeneration. } \\
\text { All three sectors }\end{array}$ \\
\hline $\begin{array}{l}\text { Inter-sectoral } \\
\text { coordination } \\
\text { and provision } \\
\text { of arbitration } \\
\text { mechanisms }\end{array}$ & $\begin{array}{l}\text { - The arbitration is carried out by the Prime Minister's office and especially the } \\
\text { Presidency of the Republic. } \\
\text { - The coordination body foreseen by the national rural sector strategy, which } \\
\text { includes mining, forestry and agriculture, among others, has not been } \\
\text { established. } \\
\text { - Conflicts between mining, agricultural and forestry operators over land use are } \\
\text { arbitrated primarily in favour of mining operators and then agro-industries. } \\
\text { All three sectors }\end{array}$ \\
\hline $\begin{array}{c}\text { Provision for a } \\
\text { monitoring and } \\
\text { evaluation } \\
\text { mechanism }\end{array}$ & $\begin{array}{l}\text { MINADER, MINFOF and MINMIDT each have services dedicated to policy } \\
\text { monitoring and evaluation. In practice, however, these services are mainly } \\
\text { concerned with centralising information on the activities of projects and } \\
\text { programmes hosted by each ministry. } \\
\text { - There are no mechanisms within these ministries with data collection tools } \\
\text { and a reporting system to assess the achievement of the objectives set by the } \\
\text { sectoral policy. }\end{array}$ \\
\hline
\end{tabular}

interviewed indicated that in practice, almost all of the titles granted to nationals for artisanal mining are subcontracted to Chinese operators. In addition, artisanal mining is an important entry point for illegality in the mining sector.

Surveys have revealed that local councils and communities receive mining royalty in a derisory manner. Moreover, very few of them know about the existence, the sharing quotas and the methods of retrocession of the said tax.

With regard to the current contribution of the mining sector to the major economic aggregates, the analysis of the data collected revealed that there are 80 formal companies employing 750 people. The cumulative turnover of these companies was estimated at CFA 25.277 billion in 2018. The contribution of the mining sector to GDP increased from CFA 15 billion in 2013 to CFA 25 billion in 2018, 


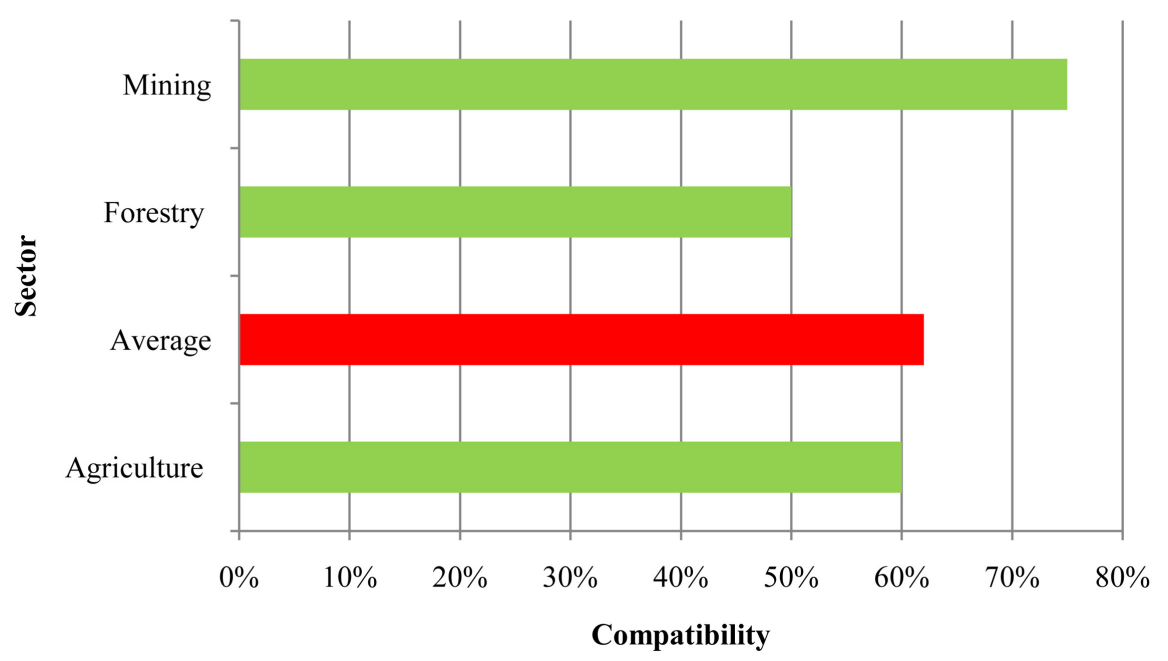

Figure 3. Compatibility of sectoral policies with the criterion of stakeholder participation in policy-making.

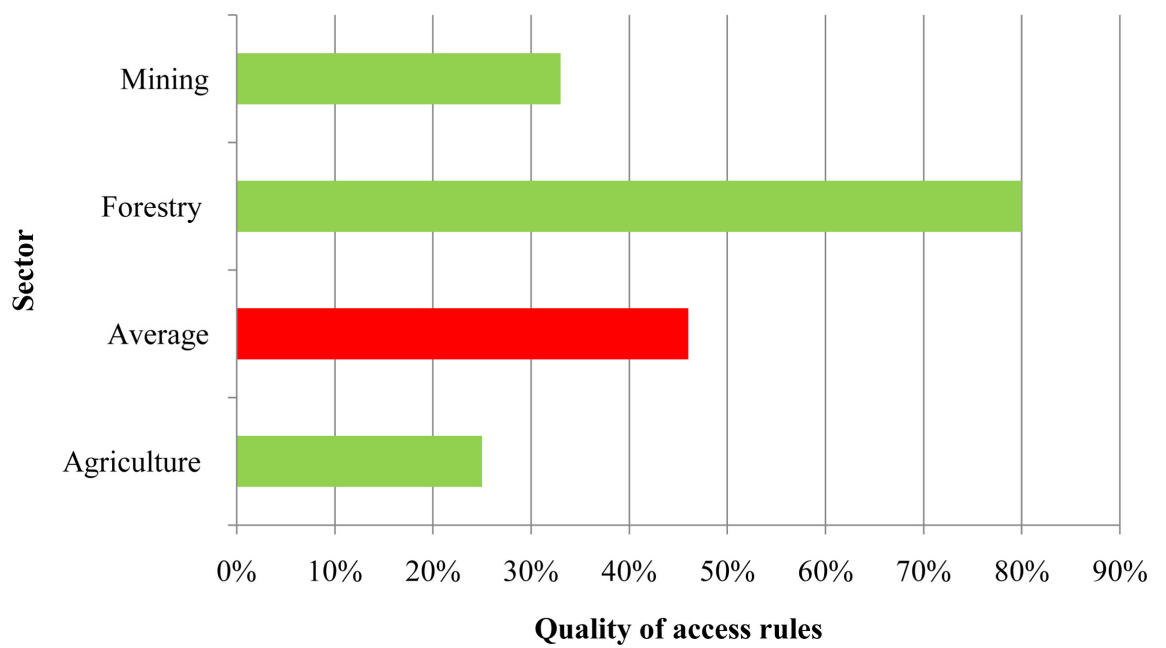

Figure 4. Compatibility of sectoral policies with the criterion of defining rules governing access to the resource.

an increase of $60 \%$. However, legal and especially illegal mining causes uncontrolled damage to the environment, including the destruction of vegetation, soil degradation and surface water pollution, to name just a few.

Ultimately, the compatibility of the mining policy with the criterion of the presence of the sustainability pillars was estimated at 35\%. The three sectors have an average compatibility of $58 \%$ with the criterion of the presence of the sustainability pillars. The forestry and agricultural sectors have a higher than average compatibility (Figure 5).

The rural sector development strategy, which includes agriculture, forestry and mining, provided for the establishment of an orientation and supervision committee under the authority of the Prime Minister. This committee was to ensure, among other things, the coordination and arbitration roles between the three sectors. However, while the various sectoral strategy documents expired in 2020, 


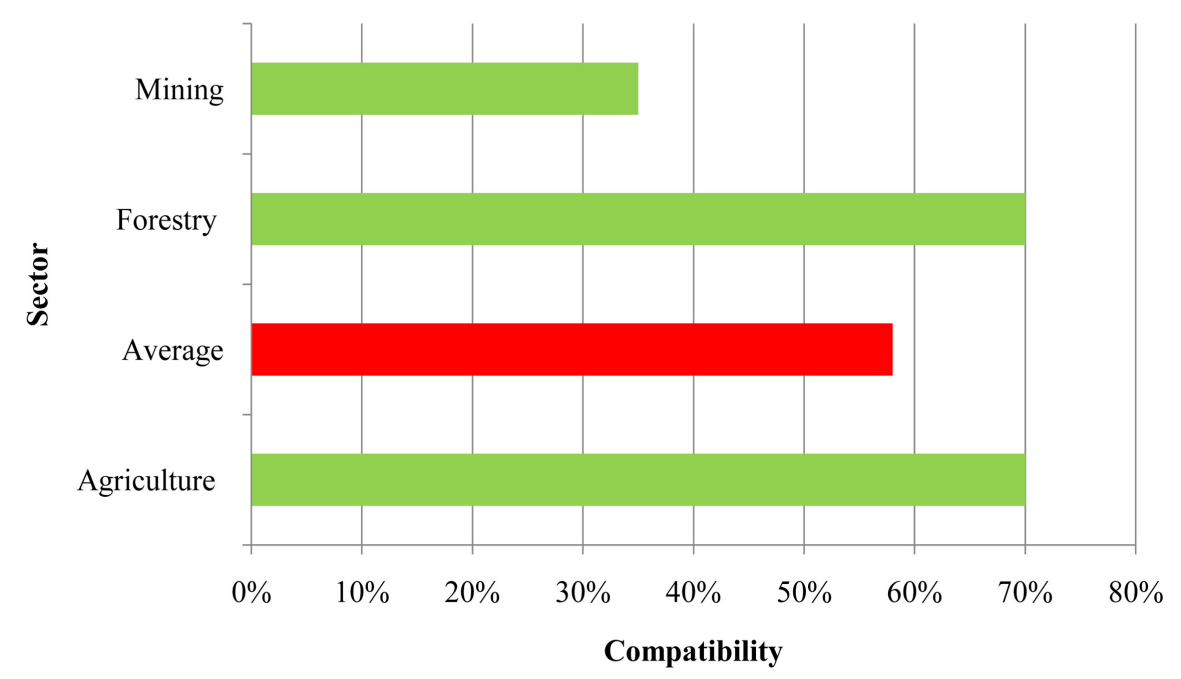

Figure 5. Compatibility of sectoral policies with the criterion presence of the sustainability pillars.

this committee has still not been established. This lack of a coordination body has not made it possible to verify the conformity of sectoral interventions with the orientations defined by Cameroon in its progress towards emergence, nor to ensure the harmony and complementarity of the intervention strategies of development partners.

The study revealed that the coordination function of the actions of the three ministries that are at the centre of the land use policies studied is weak. In fact, the permanent consultation and dialogue expected at the highest level between the actors involved in land use does not take place. The government functions in a very compartmentalised manner and consequently there is little functional coherence in the actions of the various ministries. Arbitration is ensured by the Prime Minister's Office when they receive petitions. In this case, they often rely on legal provisions and respect of administrative procedures to decide. Generally, the boundaries of the oldest concession awarded are often used as a reference for the decision. On the other hand, when there is a legal vacuum, the file is referred to the Presidency of the Republic, which makes the final decision, taking into account economic, political and geostrategic interests. Surveys have shown that when there are conflicts between mining, agricultural and forestry operators over the use of land, arbitration is most often in favour of the mining operators and then the agro-industries in the name of the principle of comparative advantage. It should be noted that this comparative advantage is judged on the basis of potential economic value, as the current contribution of mining to the Cameroonian economy is the lowest of the three sectors. Furthermore, the downgrading of forest concessions for other uses is not systematically followed by the regazettement of new areas as required by the forestry law.

Another actor that has an important influence on the arbitration of land use conflicts in Cameroon is development partners. They sometimes act in a concerted manner to tip the balance in favour of their interests. This raises the question of 
ownership of national development policies by the State and the consideration of the real aspirations of the people.

The level of compatibility of the three sectors with regard to coordination and arbitration mechanisms was estimated at $25 \%$. In fact, this is the proportion found in each of the sectors studied.

Monitoring and evaluation activities help facilitate the steering and management of policies by enabling the stakeholders concerned to know and appreciate the progress of initiated actions. To achieve this, the sectors must put in place accountability systems capable of producing reliable, relevant and timely information on the performance of their policies. The study found that MINADER, MINFOF and MINMIDT each have organic structures dedicated to monitoring and evaluating the policies of their respective sectors. However, these bodies are much more concerned with centralising information on activities of projects and programmes hosted by each ministry. There are no mechanisms within these services with data collection tools and a reporting system to assess the achievement of the objectives set by the sectoral policy.

The level of compatibility of the three sectors with respect to monitoring and evaluation mechanisms is $33 \%$, which is the percentage found in each of the sectors studied.

The compatibility of the three sectoral policies with SFM consisted of determining the level of consideration of the various criteria by each sector individually and by the three sectors put together. Compatibility rates ranged from $40 \%$ for the mining sector to $52 \%$ for the forestry sector. The application of the weighted average showed that the compatibility of the three sectoral policies with SFM is $45 \%$ (Figure 6).

Based on the results of the compatibility analysis, we were able to determine the causes of the observed incompatibility between the three sectoral policies studied (Table 6).

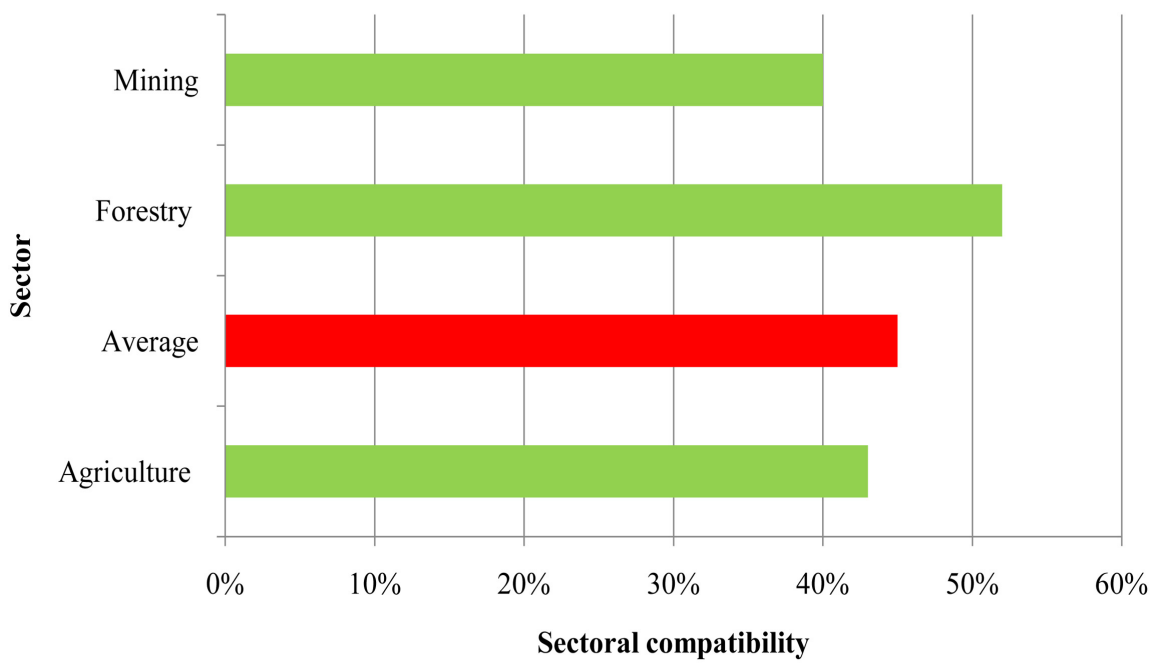

Figure 6. Compatibility of the three sectoral policies with the criteria of sustainable forest management. 
Table 6. Causes of incompatibility per assessment criteria.

\begin{tabular}{|c|c|}
\hline Analysis criterion & Causes of incompatibility \\
\hline $\begin{array}{l}\text { Stakeholder participation in } \\
\text { policy-making }\end{array}$ & $\begin{array}{l}\text { - Failure to involve all key public administrations } \\
\text { in policy-making } \\
\text { - Low involvement of the RLAs, local communities and } \\
\text { - WGOs } \\
\text { - Weak leadership of the Cameroonian State } \\
\text { - Sectoral policy-making context (structural adjustment, } \\
\text { economic liberalisation) }\end{array}$ \\
\hline $\begin{array}{l}\text { Definition of rules governing } \\
\text { access to the resource }\end{array}$ & $\begin{array}{l}\text { - Lack of inventory of agricultural land at country level and } \\
\text { in the various ecological zones } \\
\text { - Partial coverage of the resource inventory (forests, mines) } \\
\text { - Weak control of sectoral land tenure, particularly in } \\
\text { mining and agriculture } \\
\text { - Highly centralised concession allocation in the } \\
\text { agricultural and mining sectors } \\
\text { - Lack of implementing instruments for the mining code }\end{array}$ \\
\hline $\begin{array}{l}\text { Presence of sustainable } \\
\text { management pillars }\end{array}$ & $\begin{array}{l}\text { - Low contribution of mining to local development } \\
\text { - Insufficient implementation of environmental } \\
\text { management plans } \\
\text { - Low efficiency of the mining tax collection and } \\
\text { sharing mechanism }\end{array}$ \\
\hline $\begin{array}{l}\text { Inter-sectoral coordination } \\
\text { and arbitration mechanisms }\end{array}$ & $\begin{array}{l}\text { - Failure to set up the earmarked coordination bodies } \\
\text { - Lack of fairness in the arbitration procedure } \\
\text { - Weak inter-sectoral coordination (administrations are } \\
\text { competing) } \\
\text { - Low effectiveness of the operational control system } \\
\text { sack of a land-use planning tool that is binding on all }\end{array}$ \\
\hline $\begin{array}{l}\text { Provision of a monitoring } \\
\text { and evaluation mechanism. }\end{array}$ & $\begin{array}{l}\text { - Lack of policy monitoring in administrations } \\
\text { - Monitoring and evaluation limited to the short term } \\
\text { (ministerial roadmaps and projects) } \\
\text { - No database to assess the strategic vision }\end{array}$ \\
\hline
\end{tabular}

The causes of incompatibility between the three sectoral policies and SFM are 21, distributed as follows: stakeholder participation in policy-making (5); definition of rules governing access to the resource (5); inter-sectoral coordination and arbitration (5); presence of the three pillars of sustainable management (3); monitoring and evaluation (3). This shows that the greatest problems of incompatibility lie in the following three areas: stakeholder participation in policy-making, definition of rules governing access to the resource, and inter-sectoral coordination and arbitration.

\section{Discussion}

The high level of stakeholder participation in the formulation of the mining policy (75\%) is explained by the fact that all relevant actors were involved in the process. However, only some of them (the state and development partners) were 
involved in the final choices. This participation of all actors is justified by a favourable national and international context. At national level, Cameroon was admitted as a member of the Extractive Industries Transparency Initiative (EITI) in 2015 just before the start of the mining code process and had to comply with the requirements of this organisation. In fact, the EITI makes the involvement of stakeholders at all stages of the extractive industries activity one of the principles of good governance. This influence of EITI member countries is corroborated by [24]. This strong participation is also justified by the adoption of the Sustainable Development Goals (SDGs) by Cameroon and the United Nations in 2015. One of the strong guidelines of the SDGs is the involvement of the private sector and civil society in the formulation of development policies.

The weak involvement of the State in the formulation of the main agricultural and forestry policy documents (policy documents and laws) is mainly linked to the fact that these documents were developed at a time when Cameroon was under structural adjustment and the revision of these documents was part of the conditions of the World Bank which strongly influenced the content of these documents. This analysis is in line with that of authors such as [2] [25], who argue that in the case of the Forestry Law, for example, development partners had a stronger influence than the State in the adoption of certain major provisions, such as the allocation of concessions through competitive bidding, the institution of an independent observer and the introduction of management plans in the management of permanent forests.

Furthermore, at governmental level, forests were managed by the Ministry of Agriculture until the creation of the Ministry of Forestry in 1992. In a desire for political affirmation, the young forestry administration did not see fit to involve other actors such as mining and agriculture in this exercise. The consequences of this non-involvement are numerous, such as recurrent land conflicts between concessionaires in the three sectors of activity or the agricultural enclaves found in several production forests in the country [26]. The non-involvement of the Ministry of Agriculture in the allocation of timber sales within the non-permanent forest estate is one of the causes of the overlap observed between these forest titles and farms, which results to conflicts between actors in the field.

The high level of compatibility of the forestry sector with the access to resources criterion $(80 \%)$ is justified by the fact that it has a database for monitoring the areas granted for logging and a general system for monitoring the evolution of forest cover. In addition, the process of allocating titles is participatory and the forestry sector has an inventory that covers the East and South Regions.

The general poor performance of the agricultural sector in terms of access to resources is mainly explained by the age of the land regulations. In fact, the main texts regulating land acquisition in the agricultural sector date from the 1970s (Ordinance No. 74-1 of July 1974 to establish the land tenure system; Ordinance No. 74-2 of 6 July 1974 to establish the land tenure system; Law No. 76/25 of 14 December 1976 on cadastral organisation), i.e. an economic context dominated by the omnipotence of the State. At present, these land laws are not in line with 
the liberal vision contained in the policy documents analysed, which make the private sector the driving force behind economic development, and thus the main actor in land acquisition.

The strong compatibility of the forestry sector with the pillars of sustainability is explained by the fact that the three main policy documents (policy, law, land use plan) were drafted between 1993 and 1995, i.e. in the aftermath of the Rio de Janeiro conference and under strong environmentalist influence. Hence the efforts noted in the control of the evolution of the resource, the involvement of other actors in the attribution of titles and the information of the general public on forestry activity. The poor performance of the mining sector in terms of control of the sectoral land tenure and opening up to other sectors in the allocation of titles reflects the State's desire to have total control over mining activity. This desire is enshrined in Section 5 of the mining code which stipulates that "mineral substances contained in the soil and subsoil of the territory of the Republic of Cameroon are the property of the State which exercises its sovereign rights thereon". This is also the case in the petroleum sector where the State, through its representatives, behaves as if it were managing the subsoil resources and the information attached to them "privately".

The weakness of the mining sector in relation to the sustainability pillars is due to insufficient regulation, weak capacity to control mining and the low impact of the mining tax on local development. In fact, there is a lack of clarification of strategic options regarding the overall deployment of the mining sector due to the absence of a mining policy document. Similarly, the absence of implementing instruments for the mining code does not allow for proper supervision of the activities of actors. The system for monitoring mining activities in the field remains weak in terms of human and material resources. [27] [28] found that the weakness of resources allocated to control encourages illegal exploitation and prevents the mining sector from playing the role that Cameroon expects of it for its economic development. With regard to mining royalties, regulations have instituted a sharing quota which prescribes that $50 \%$ of the revenue generated by the ad valorem tax on the sale of minerals will go to the public treasury, $25 \%$ to the ministry in charge of mines for the control and monitoring of mining activities, $15 \%$ to the councils where mining takes place, and $10 \%$ to the communities affected by exploitation activities. Despite these provisions, the local population only receives mining royalty in a derisory manner and very few of them are aware of the existence of these texts [29].

Official figures published by the National Institute of Statistics [30] [31] confirm that the agricultural sector is the largest contributor to GDP and job creation. Also, despite the privileged place of mining in the country's economic policy, among the three sectors the mining sector contributes lowest to the major economic aggregates.

Apart from a lack of holistic vision on land management attributable to the functioning of the state, the weakness of coordination in the management of the three sectors is also explained by the fact that the pilot initiatives conducted in 
terms of integrated natural resource management are not capitalised on at national level. An example is the management initiative of the Sangha Trinational in the East Region and the Ngoyla-Mintom forest stand in the South Region. Also, Cameroon does not exploit all the opportunities offered by its laws to manage its agricultural, forestry and mining potential in a holistic and integrated approach. This is the case, for example, with Law No. 2011/008 of 6 May 2011 on the orientation of sustainable development and planning, which sets out the guiding principles of the policy on sustainable development and planning of the national territory. This law should serve as a source of inspiration for the harmonisation of sectoral policies and the promotion of integrated management of lands and resources. This weak coordination can have various types of consequences, including the lack of legibility of the overall results achieved in the march towards emergence and the risk of duplication in the conduct of sectoral activities. Also, this weak inter-sectoral coordination is at the root of various types of land use conflicts between stakeholders [18] [32].

The fact that the arbitration of conflicts between the three sectors is always to the detriment of forests without regazettement of other forest stands undermines national forestry policy and may have negative repercussions internationally. In fact, the choice of where to locate a protected area or a production forest is based on the ability of the selected area to meet specific objectives better than others. Consequently, the downgrading of a concession or protected area to a mining or agricultural concession inevitably undermines national conservation and SFM objectives [33]. At international level, these practices may ultimately undermine Cameroon's international commitments to the implementation of certain international conventions such as the UN Convention on Biological Diversity. This state of affairs may also harm relations between Cameroon and the partners that support it in its conservation and SFM efforts.

\section{Conclusions}

The alignment of sectoral policies is essential to promote sustainable forest management in Cameroon. This study showed that Cameroon's forestry, agricultural and mining policies have an average level of compatibility of $45 \%$ with sustainable forest management and 21 explanatory causes of this incompatibility were identified.

To help reduce this incompatibility, four types of measures have been proposed. They are:

1) Improving the legal and regulatory framework of the three sectors of activity through the conduct of a participatory land reform, the revision of the forestry law and policy as well as the formulation of a mining policy document and the production of the various implementation instruments of the mining code.

2) Developing databases for to follow-up sectoral policies and land tenures, including the establishment of a legal alert system in each of the three ministries 
(MINADER, MINFOF and MINMIDT) and computerised systems for the management of sectoral land tenures.

3) Developing land-use planning tools, including a national land-use plan and establishing a robust mining control system.

4) Improving the institutional framework through the establishment of an arbitration and coordination body for the rural development strategy chaired at the top of administrative power (President of the Republic, Prime Minister) and creating a national land observatory.

\section{Acknowledgements}

This study was carried out as part of the writing of a $\mathrm{PhD}$ thesis at the International University of Applied Sciences for Development (IUASD) in collaboration with the Pan African Institute for Development (PAID). The authors are grateful to IUASD and PAID for guiding the study and to Center for International Forestry Research (CIFOR) for logistical support in finalizing the publication.

\section{Conflicts of Interest}

The authors declare no conflicts of interest regarding the publication of this paper.

\section{References}

[1] Eba'aAtyi, R., Devers, D., De Wasseige, C. and Maisels, F. (2010) State of Central African Forests 2008. OFAC, Washington.

[2] Topa, G., Megevand, C., Karsenty, A. and Debroux, L. (2009) The Rainforests of Cameroon: Experience and Evidence from a Decade of Reform. The World Bank, Washington, 226 p. https://doi.org/10.1596/978-0-8213-7878-6

[3] Eba’aAtyi, R., Lescuyer, G., NgouhouoPoufon, J. and MoulendeFouda, T. (2013) Étude de l'importance économique et sociale du secteur forestier et faunique au Cameroun. MINFOF/CIFOR, Yaoundé, 315 p.

[4] MINFOF (2018) 2017 Statistical Yearbook of the Ministry of Forests and Wildlife. $107 \mathrm{p}$.

[5] MINEPAT (2009) Growth and Employment Strategy Document. 167 p.

[6] MINFOF (2012) Cameroon 2020 Strategy for the Forest and Wildlife Sub-Sector.

[7] Mevegand, C., Mosnier, A., Houticq, J., Doetinchem, N. and Streck, C. (2013) Dynamics of deforestation in the Congo Basin: Reconciling economic growth and forest protection. The World Bank, Washington, $201 \mathrm{p}$. https://doi.org/10.1596/978-0-8213-9742-8

[8] Tchatchou, B., Sonwa, D, J., Ifo, S. and Tiani, A.M. (2015) Deforestation and Forest Degradation in the Congo Basin State of Knowledge, Current Causes and Perspectives 120. CIFOR, Yaounde.

[9] Paul, E., Zinnen, V. and Dujardin, B. (2011) L'approche Sectorielle. GRAP-PA Santé.

[10] Muller, P. (2008) Les politiques publiques. Presses universitaires de France, Paris.

[11] Fukasaku, K. and Hirata, A. (1995) The OECD and the ASEAN Economies: The Challenge of Policy Coherence. OECD Development Centre, Paris, 20.

[12] MINEF (1995) Zoning Plan for Southern Cameroon Forest Zone. 
[13] MINAGRI (1990) Reorientation of Cameroon's Agricultural Policy.

[14] MINADER (2006) Rural Sector Development Strategy. Summary of the Agriculture and Rural Development Component.

[15] MINADER (2015) Cameroon National Agricultural Investment Plan 2014-2020. Volume 1 .

[16] Mason, J. (2002) Qualitative Researching. 2nd edition, Sage, London, 223 p.

[17] Dubé, Y.C., Lange, G.-M. and Schmithüsen, F. (2005) Cross-Sectoral Policy Linkages and Environmental Accounting in Forestry. Journal of Sustainable Forestry, 23, 47-66. https://doi.org/10.1300/J091v23n03 02

[18] Kengoum, F., Assembe-Mvondo, S., Eba'a Atyi, R., Levang, P. and Fomete, T. (2016) Cameroon's Forest Policy within the Overall National Land Use Framework: From Sectorial Approaches to Global Coherence? International Forest Review, 18, 11 p. https://doi.org/10.1505/146554816819683762

[19] Ondoa, M. (2006) Analyse des politiques agricoles mises en œuvre au Cameroun depuis $1960.69 \mathrm{p}$.

[20] Ondoa, M. and Ayong, E. (2013) Revue des politiques, stratégies, programmes et projets de développement rural au Cameroun. $59 \mathrm{p}$.

[21] FAO (2010) Developing Effective Forest Policy—A Guide. FAO, Roma, 99 p.

[22] MINFOF (2019) GLAD $20084^{\text {th }}$ Quarter Bulletin. 36 p.

[23] Défoukouémou, H. (2018) The New Cameroonian Mining Code, at the Heart of the Standards of Contemporary Extractive Governance.

[24] Ekoko, F. (1997) The Political Economy of the 1994 Cameroon Forest Law. Working Paper, CIFOR, Yaoundé.

[25] Guillaume, L., Alexandre Emerit, E.E.M. and Joseph, J.S. (2001) Community Involvement in Forest Management: A Full-Scale Experiment in the South Cameroon forest. Rural Development Forestry Network, 25C.

[26] Lickert, V. (2012) Mineral Resources in Cameroon: Governance, Decision Making and Second Opinion. Private Actors in Mining Governance in Cameroon. Université Paris 1, Paris, 164 p.

[27] Tchindjang, M., Mbeyo, F.P., Haman, U., Voundi, E., Njombissie, P.I. and Saha, F. (2017) Mines against forests and conservation in Cameroon: Issues of environmental assessment of the mining sector for sustainable development in Cameroon. $38 \mathrm{p}$.

[28] FODER (2016) Secteur minier un trou noir de développement. Ressources, , 28 p.

[29] INS (2018) Répertoireetdémographie des entreprisesmodernes en 2017. 5ème Edition.

[30] INS (2019) 2018 National Accounts.

[31] Ongolo, S. (2015) On the Banality of Forest Governance Fragmentation: Exploring "Gecko Politics" as a Bureaucratic Behavior in Limited Statehood. Forest Policy and Economics, 53, 12-20. https://doi.org/10.1016/j.forpol.2015.01.005

[32] Nkoulou, J. (2021) Sectoral Policies for Land Use and Sustainable Forest Management in Cameroon. PhD Thesis, International University of Applied Development Sciences.

[33] Nguiffo, S. and Kenfack P.E. (2011) Legislation on Extractive, Land, Forestry and Environmental Activities in Cameroon. Perspective and Conflict Management. 